University of Nebraska - Lincoln

DigitalCommons@University of Nebraska - Lincoln

Faculty Publications, Department of History

History, Department of

Summer 2011

\title{
From Bloodless Revolution to Bloody Counterrevolution: The Adana Massacres of 1909
}

Bedross Der Matossian

University of Nebraska-Lincoln, bdermatossian2@unl.edu

Follow this and additional works at: https://digitalcommons.unl.edu/historyfacpub

Part of the History Commons

Der Matossian, Bedross, "From Bloodless Revolution to Bloody Counterrevolution: The Adana Massacres of 1909" (2011). Faculty Publications, Department of History. 124.

https://digitalcommons.unl.edu/historyfacpub/124

This Article is brought to you for free and open access by the History, Department of at DigitalCommons@University of Nebraska - Lincoln. It has been accepted for inclusion in Faculty Publications, Department of History by an authorized administrator of DigitalCommons@University of Nebraska - Lincoln. 


\title{
From Bloodless Revolution to Bloody Counterrevolution: The Adana Massacres of $1909^{1}$
}

\author{
Bedross Der Matossian \\ University of Nebraska-Lincoln
}

\begin{abstract}
The historiography of the Adana Massacres of 1909 is represented by two diverging views. While some Turkish scholars deny the involvement of the local government officials in the massacres by putting all of the blame on the Armenians who revolted as part of a conspiracy to establish a kingdom in Cilicia, some Armenian scholars, whose work is overshadowed by the Armenian genocide, accuse the Committee of Union and Progress (CUP) of acting behind the scenes to destroy the Armenian economic infrastructure in Adana in order to curb any future political and economic development in the area. By deviating from the existing historiography, the present article contends that the Adana Massacres should be viewed as part of the revolutionary process which led to the erosion of social and political stability in the region, the creation of weak public-sphere institutions, and intensification of the existing economic anxieties, all of which led to the enactment of violence against the vulnerable Armenian population of Adana. Understanding the factors and the motives that led to the enactment of violence will shed new light on understanding the future acts of violence perpetrated against the indigenous Armenian population of the Ottoman Empire.
\end{abstract}

Keywords: Ottoman Empire, violence, revolution, massacres, Armenians, public sphere

On 29 August 1908, one month after the Young Turk Revolution, Mihrdat Noradoungian, an Armenian intellectual from Istanbul, wrote a lengthy opinion piece entitled "The Price of Freedom" in the Armenian daily newspaper Puzantion. In this lengthy article, Noradoungian argued that people were looking with hesitation at this freedom that came about without any bloodshed. What Noradoungian was implying in the article is that the Freedom after the revolution should have been received through violence-probably reminiscent of the violence during the French Revolution which was able to get rid of the ancien régime:

The change that took place a month ago had the biggest peculiar advantage, to which the entire world views with bewilderment, and that is the lack of blood and uproar. Both of these factors are regular phenomenon in these kinds of situations... Though during the [last] 15 years a lot of blood has spilled, there was the fear of greater bloodshed which did not happen. One should know that this [bloodshed] has become a natural law and that natural laws are unavoidable. Whatever did not happen in the beginning could still happen. Whatever the revolution did not do, the counterrevolution will be able to do. There is only one way in order to prevent the occurrence of this contingency (bloodshed) and that is discretion, modesty, wisdom, and patience. New freedom is always fragile. Let us be careful. ${ }^{2}$ 
This connection between Revolution, Blood, and the ancien régime was endemic and not only to the Armenian press in the Ottoman Empire. During the first days of the constitution, while the revolutionary festivities were at their height, the ethnic presses (Armenian, Arabic, Greek, Ottoman Turkish, and Ladino, among others) warned people to be vigilant about the existing fragile situation and be wary of former officials of the ancien régime. ${ }^{3}$ However, in comparison to other newspapers, the Armenian press dealt intensively with the concept of the ancien régime in its present form, not in its past one. ${ }^{4}$ One such editorial sought to enlighten the public about the danger of the situation and the calamities that they should expect. ${ }^{5}$ The article is crucial in that it predicts the upcoming calamity of the counterrevolution. It advised Armenians to not create any pretext for the eruption of these agitations. On the contrary, the editorial argued that it is the duty of the Armenians to act with love toward their Turkish brothers and be careful with every act and every word that could make them bitter against Armenians and incite the people of the ancien régime. "We repeat that we need to be careful from shouting 'Armenian,' or to talk about an independent Armenia," argued the editorial. "The majority of the nation is in agreement that reforming the condition of the Armenians of Turkey is dependent on the reform of Turkey." The editorial ends by recommending that Armenians cooperate with their Turkish compatriots "who support us and curse the ancien régime." 6

With this connection between revolution and blood in mind, the present article discusses the correlation between the 1908 revolution and the Adana Massacres of 1909. After briefly reviewing the existing historiography of the Adana Massacres, I will introduce a new approach to the understanding of these massacres in the larger context of the revolution, specifically the development of a weak public sphere and the erosion of social and political stability, all of which led to the escalation of violence in Adana. Afterward, I will discuss the impact of the Young Turk Revolution on Adana and demonstrate the ways in which the revolution precipitated the ethnic tensions leading to the massacres.

\section{The Young Turk Revolution of 1908}

The Young Turk Revolution of 1908 represents an important historical juncture in Ottoman history and the history of the modern Middle East, not as a new beginning, but rather as a major catalyst in accelerating the dissolution of the empire. Thus, these two contradicting paradigms of a new beginning and dissolution were interconnected and went hand in hand in marking the last phase of Ottoman history, the Second Constitutional Period (1908-1918) that ended with the defeat of the empire in World War I Within this period two interrelated events took place that shaped the political scene of the era: (1) The counterrevolution of 31 March 1909 which was initiated by the reactionary forces within the empire and (2) the Adana Massacres (April 14-17, April 25-27) which led to the destruction of the physical and the material presence of Armenians in Adana.

The counterrevolution was not a spontaneous outburst by dissatisfied elements in Istanbul; rather, it was organized by oppositional elements mainly represented by conservative religious circles within the empire. ${ }^{7}$ On the night of April 12, the troops of the First Army Corps mutinied and marched toward Ayasofya Square, near the parliament, accompanied by a large number of people in religious garb (softas) shouting slogans in favor of the sultan and demanding the restoration of the Sher'ia. ${ }^{8}$ This resulted in the resignation of Hilmi Pasa's cabinet, which was promptly accepted by the sultan. ${ }^{9}$ By royal order, on April 14, Tevfik Pasa was appointed the Grand Vezir and Ismail Kemal 
was elected the President of Parliament. ${ }^{10}$ This was a huge blow to the Committee of Union and Progress (CUP) whose members either fled or were hiding. On April 17 the CUP began to act. The Action Army (Haraket Ordusu) left Salonika and headed to Istanbul to restore public order and discipline among the rebellious troops. It established its headquarters at Aya Stefanos and began negotiations with the new cabinet. ${ }^{11}$ After failed negotiations, the Action Army entered Istanbul on April 23 and, after several skirmishes, took control of the city.

The Adana Massacres of 1909, which became a turning point for the Armenians living in the Ottoman Empire, were one of the earliest manifestations of violence during the Second Constitutional Period (1908-1918). Furthermore, the massacres represent a microcosm of the deterioration of ethnic conflict in Anatolia and its culmination in the destruction of the indigenous Armenian population during World War I Understanding the factors and motives that led to the enactment of violence will shed new light on the future acts of violence perpetrated against the indigenous Armenian population of the Ottoman Empire. The present article contends that the Adana Massacres should be viewed as an integral part of the ongoing power struggle in Anatolia and the Arab provinces after the revolution. ${ }^{12}$ An important factor that contributed to the escalation of ethnic tensions was the emergence of a weak public sphere within the empire after thirty years of the Hamidian despotic regime. Hence, to better understand the escalation of ethnic tensions in the empire, it is important to problematize the notion of modern public sphere and understand its implications and challenges within the Ottoman milieu. ${ }^{13}$ Doing so will provide us with better ways of understanding communal violence as a by-product of modernity.

\section{The Public Sphere and the Ottoman Empire}

The notion of the public sphere refers to a social space in which private citizens gather as a public body with the rights of assembly, association, and expression in order to form public opinion. ${ }^{14}$ The history of the notion of the public sphere in the Ottoman Empire has yet to be written and the present study does not undertake that task. ${ }^{15}$ Of course, the public sphere, both in its pre-modern and modern forms, existed in the Ottoman Empire. ${ }^{16}$ However, it had a different background and was affected by different factors from the European milieu. ${ }^{17}$ As a result of modern urban development, the public sphere began to enter into its modern form. The modern public sphere(s) in the empire was spurred by the development of peripheral capitalism and through the opening of urban spaces, in the form of public squares, gardens, and wider roads. In addition, the process was accompanied by the proliferation of cafés, associations, theaters, and scientific and literary societies, as a result of which literary public spheres were formed in the empire. However, the main factor that led to the proliferation of these public spheres in the empire during the nineteenth century was the press in general and newspapers in particular. ${ }^{18}$ The official Ottoman press began to be published in the nineteenth century and was followed by the emergence of the private press. The transformation of the literary public spheres into political public spheres in the modern sense took place throughout the century, reaching its peak with the promulgation of the Ottoman constitution in $1876 .{ }^{19}$ In fact, the creation of the private press and the proliferation of the ethnic press in the second half of the nineteenth century further developed the notion of multiple public spheres as opposed to the public sphere dominated by the Ottoman ruling elite.

In 1878, however, Sultan Abdülhamid dissolved the Ottoman parliament and derailed the constitution, putting an end to the political public sphere. Hence, the institutions that 
once served as the basis of the developing public sphere(s) were derailed and weakened. He also established one of the most sophisticated spying systems in the history of the Ottoman Empire. As a result, by the beginning of the 1880s, the ethnic groups' journalist activities shifted West, from Lebanon, Syria, and Anatolia to European cities and Egypt. Here, an exilic public sphere was established in which exiles of different ethnic backgrounds expressed their political views, discussed their projects for the empire, interacted with each other, and attempted to mobilize their host governments by using various means of expression, from exilic media to public gatherings and discussion. ${ }^{20}$

After the Young Turk Revolution of 1908, this exilic public sphere was transformed into a homeland public sphere. The revolution allowed for an immediate boom in the serial publications of different ethnic groups in the empire. ${ }^{21}$ In the two years after the revolution, censorship was nonexistent. In the first year alone about 200 periodicals were published in Istanbul. ${ }^{22}$ Hence, the media that served the development of multiple/competing public spheres prior to the Hamidian period were reinstated during the post-revolutionary period. However, these contentious and weak public sphere(s) that lacked strong institutional basis would become the medium through which the existing tensions in the empire were going to surface, demonstrating the incompetence of the local administration to deal with contentious situations. The weak public sphere(s) became a medium through which both the satisfied and the dissatisfied elements aired their content or discontent with the new regime and deliberated the political future of the empire by using the tools of modernity. In addition, the weak public sphere(s) also became an important vehicle for the enactment of violence by the dissatisfied groups. Thus, the relationship between public sphere and violence is crucial to understanding the massacres carried out against the indigenous Armenian population. After the revolution, the growth in Adana's public sphere not only fomented political activism within formerly outlawed groups, but it also contributed to an escalation of ethnic tensions. The physical and verbal manifestations of Armenians in the public sphere in the forms of cultural and political processions, the bearing and selling of arms in public, ${ }^{23}$ and theatrical presentations as well as the use of print media sent alarming vibes among the dissatisfied elements, which began to use the same medium to air their anxieties about and discontent with the new created order. Thus, the public space in Adana would become not only the place for the re-enactment of identities; it would also become a vehicle through which the existing political, social, and economic anxieties would be manifested in two waves of massacres which took place in conjuncture with the counterrevolution.

\section{Historiography and the Adana Massacres of 1909}

The study of ethnic strife, violence, and repression in the Ottoman Empire in general and in Anatolia in particular remains marginalized in the historiography of the Ottoman Empire. Only a handful of scholars have attempted to put these subjects at the core of their inquiries. ${ }^{24}$ However, most of these works concentrate on the Armenian Genocide during World War I and do not consider the incidents of violence prior to the war. ${ }^{25}$ Other scholars attempt to represent the acts of violence that took place at the end of the nineteenth and the beginning of the twentieth centuries as part of a linear process that culminated in the extermination of the Armenians. ${ }^{26}$ A major methodological deficiency of these works stems from the failure to appreciate that violence during the early phase of the Second Constitutional Period was an integral part of the revolutionary process. While some Turkish scholars deny the involvement of local government officials in the massacres 
by blaming the Armenians who revolted as part of a conspiracy to establish a kingdom in Cilicia, ${ }^{27}$ some Armenian scholars, whose work is overshadowed by the Armenian genocide, accuse the CUP of acting behind the scenes to destroy the Armenian economic infrastructure in Adana in order to curb any future political and economic development in the area. ${ }^{28}$

\section{Development of Adana's Public Sphere(s)}

It is impossible to understand the development of Adana's public sphere without understanding the impact of the revolution on the Anatolian provinces and the ways in which it led to the emergence of contentious public sphere(s). The Young Turk Revolution caused major changes in the dynamics of power within the provinces, leading to an erosion of social and political stability. By disturbing a thinly balanced power equilibrium, the revolution produced a great deal of dissatisfaction within some segments of the population. The sudden mushrooming of Young Turk cells and clubs in the provinces caused extreme anxiety among the notables and the ulema (religious clerics) in the Anatolian provinces. Although the CUP had branches in all Anatolian and Arab provinces, it was not in full control of the provinces. A major factor in the deterioration of the intra-ethnic relationship among the Muslims in Anatolia was the dismissal of local officials and their replacement with CUP members or people loyal to the CUP. This contributed immensely to the rising tension between the CUP and the people of the ancien régime, mainly because a whole stratum of notables who had benefited from the ancien régime had lost power. Hence, one cannot understand the changes in Adana after the 1908 revolution without understanding the regional waves of discontent manifested after the revolution, especially in the Anatolian provinces. What distinguished Adana from other provinces was its economic and agricultural centrality to Anatolia - which attracted thousands of migrant workers arriving from Hadjin, Erzerum, Bayburt, and Bitlis - and its complex ethnic composition, which was a main catalyst in the deterioration of this ethnic relationship. ${ }^{29}$ Therefore, I argue that the conditions created after the revolution and the emergence of contentious public sphere(s) prepared the ground for a violent backlash.

Adana was also an important spiritual and economic center for Armenians in Anatolia. It housed the Sea of the Catholicosate of Sis (Kozan). ${ }^{30}$ In addition, the city had eight churches, two of which were Gregorian, one Protestant, and one Catholic. There were also Greek, Syrian, and Chaldean churches. ${ }^{31}$ Armenians had two schools, the Apkarian and the Ashkhenian schools, the French had the Jesuit missionary school for boys and girls, and the Americans had the Girls College. In Tarsus, Americans also had St. Paul's Institute College. ${ }^{32}$

Prior to the massacres of 1909, Adana's population consisted of 62,250 Muslims; 30,000 Armenians; 5,000 Greeks; 8,000 Chaldeans; 1,250 Assyrians; 500 Christian Arabs; and 200 foreign subjects. ${ }^{33}$ The Muslim population of Adana included Turks, Kurds, Fellahs, Circassians, Avshars, Cretans, and nomads. In addition, every spring about 30,000-40,000 migratory workers would come to Adana from Aleppo, Harput, Sivas, Diarbekir, Erzerum, Hajin, Bitlis, Bayburt, and Erzerum to work as farmers, tilling, reaping, and cultivating the cotton fields, or to work in factories. ${ }^{34}$ The Muslim migrant workers always exceeded the Armenian migrant workers by a ratio of 2:1.

Adana was also the center of the cotton trade on the Cilician Plain. ${ }^{35}$ David Fraser who visited Adana prior to the 1908 revolution argued that at the end of the nineteenth century it was customary for 60,000 laborers to visit Cilicia annually for the purpose of assisting with the harvest. However, he argues that this annual migration had ceased at the beginning 
of the twentieth century because the resident population aided by steam ploughs, steam threshers, and reaping machines was not able to undertake the labor by itself. This point is extremely important because it demonstrates the ways in which the introduction of modern agricultural and production technologies have caused substantial dissatisfaction among the migrant workers who used to benefit from the pre-modern agricultural mediums and has created what Ayhan Aktar calls "accumulated envy" toward the Armenians. ${ }^{36}$ This "accumulated envy" would reveal itself in violent backlash by the migrant workers against the Armenians. In addition to this, Adana also housed several large establishments involved with ginning, spinning, and weaving. Among these, the most important factory was owned by the Greek Trypani Brothers who introduced the cotton industry to Cilicia. ${ }^{37}$ In addition, the Deutsche Levant Cotton Company, which was financed by German, Swiss, and Austrian financiers, was also active in the region. ${ }^{38}$ The Armenian population was very involved in trade and industry. They played a predominant role in exporting materials from Adana. ${ }^{39}$ Armenian sources indicate that Armenian prosperity in Adana was lamented by some Turkish notables, such as Abdü lkadir Bagdadizade, one of the most influential notables in Adana. ${ }^{40}$

\section{The Ottoman Public Sphere in Adana: The Climax of Contentious Politics between the CUP and the Notables}

As soon as the constitution was enacted, people in Adana and Mersin began rejoicing. Masses were held in honor of the sultan and the Ottoman nation. ${ }^{41}$ However, these festivities of the revolution were only euphoric feelings that did not reflect the different social sectors' actual attitudes toward the revolution. The revolution and the reinstatement of the constitution in Adana led to the rise of new figures. Ihsan Fikri, a self-acclaimed Young Turk, suddenly became a public figure. Fikri played an important role in organizing festivities in honor of the revolution. At the end of the festivities, Fikri sent a congratulatory telegram to the CUP branches in Manastir, Salonica, and Istanbul on behalf of the people of Adana. The next day the CUP Central Committee asked Fikri to establish a CUP branch in Adana. ${ }^{42}$ To counter the CUP's influence, Abdü lkadir Bagdadizade, ${ }^{43}$ one of the most influential notables of Adana, formed a group called the Agricultural Club (Zirâ at Kulübü ) composed of Adana notables, people from Idlib, and softas. ${ }^{44}$ They were supported by another anti-CUP committee, the Scientific Committee (Cemiyet-i Ilmiye). As with the other CUP branches in the provinces, people from the ancien régime entered the ranks and the first task of the new CUP branch was to force the local vali (governor) to resign. ${ }^{45}$ Bahri Pasa resigned and for some time the CUP branch administered the province. It also succeeded at removing Kâzim Bey, the chief of police ( polisemüdürü ), and police superintendent (komiser) Zor Ali from their positions. ${ }^{46}$ In addition, the CUP began sending delegates, consisting of one Armenian and one Turk, to villages to preach to the masses about the constitution. In order to better understand the tension that arose between the CUP and the local notables, it is important to give a brief historical background of Ihsan Fikri.

Ihsan Fikri, whose original name was Ahmed Tosun, had been an officer of the Salonica Agriculture Department. He was later exiled to Diyarbekir and then to Payas. After his exile to Payas, he represented himself as a liberal. Bahri Pasa, the vali, interceded with the authorities on his behalf to end his exile. ${ }^{47}$ After returning to Adana, he married the daughter of a local property owner by the name of Menan Bey. Prior to the revolution, Fikri had been the principal of the Handicraft School (Sanayi Mektebi) but was fired by 
the vali, who replaced him with Gergerlizade Ali Effendi. After the revolution and the establishment of the CUP branch in Adana under his leadership, Fikri began to persecute his opponents, particularly Gergerlizade. ${ }^{48}$ As a result, two groups emerged in Adana, one supporting Fikri and another supporting Gergerlizade. ${ }^{49}$ This tension can be best defined as CUP versus the local notables. In this intra-ethnic struggle the press played an important role. In the post-revolutionary period five newspapers were published in Adana: Seyhan, Yasasin Ordu, Itidal, edited by Ihsan Fikri; Rehberi Itidal, owned by Ali Ilmi Effendi; and Çukurova, a weekly newspaper published by Mahmud Jelaleddin. Itidal and Rehberi Itidal were in constant conflict. The latter was also supported by Çukurova. According to Terzian, Ihsan Fikri wrote erratically, praising the Armenians one day and attacking them the next.

After Bahri Pasa resigned, he was replaced by Mirliva Ali Pasa, who generally kowtowed to the CUP. When Cevad Bey was appointed vali, tensions began to escalate dramatically. Ihsan Fikri, seeing Cevad Bey's weakness, tried to manipulate him into removing Gergerlizade from his position as the principal of the school. Gergerlizade, however, gained the vali's favor. In addition, Cevad Bey used to frequently visit the Agricultural Club and the Scientific Committee. ${ }^{50}$ This angered Fikri, who began openly attacking the vali in Itidal, even calling for his resignation, but to no avail. ${ }^{51}$ Furthermore, he claimed that government was nonexistent in Adana and that it was people like Abdülkadir Bagdadizade who were truly running the affairs of the country. In this tensed atmosphere, Zor Ali, the former police commissary (komiser) of Adana who had been dismissed by the CUP, arrived in Adana and declared himself a member of the Fedakâ rini Millet, a branch of the Ittihadi Mouhamadi, and called on people of the same mind to join him. ${ }^{52}$ In this atmosphere of intra-ethnic tension, news of the counterrevolution reached Adana, further altering the power balance within the provinces.

\section{The Armenian Public Sphere: Testing the Limits of Freedom}

The Armenian festivities and demonstrations in honor of the constitution on 24 July 1908 were especially striking. The public sphere created after the 1908 revolution allowed Armenian political parties to be active in Adana. Armenian cultural revival began. Poetry, odes, and dramas about the Armenian national past began to be published and performed, causing anxiety among the local Muslim population. In addition, Armenians, "intoxicated with the new wine of liberty, often gave offense by wild talk or arrogant behavior." 53 In an interview with an Armenian newspaper after the massacres, missionary Christie positioned at Tarsus argued that there is no proof that the Christians as a whole desired separation from the Ottoman people or government. Granted, he argued that there were a very few foolish men (Armenians) who by their boasting and threats exasperated the Turks. However, he adds that "their acts and words ought not to be taken as justifying in the slightest degree the cruelties that make this recent massacre worse than any that have gone before it." 54 Armenian activities in the post-revolutionary period entailed physical and verbal manifestations in the public sphere causing much anxiety among the dissatisfied elements. For example, Itidal, the main Young Turk organ in Adana edited by Ihsan Fikri, reported that on Sunday 29 March 1909 a play was performed by Armenians at the Casino of Ziya Pasa in Mersin. ${ }^{55}$ In the words of one contemporary Ottoman official in Adana, "At that night Armenians had opened the first curtains of revolt" (Iste Ermeniler ilk isyan perdesini o gece açmislardir). ${ }^{56}$ The play was entitled Temurlane and the Destruction of Sivas. ${ }^{57}$ The local mutessarif (subgovernor), as well as other officials, was invited to attend 
the play. At the beginning of the play, Temurlane gives an order to exterminate all the Armenians. A fierce struggle takes place between Temurlane and an Armenian king. The king, along with his servant and his daughter, becomes Temurlane's prisoner. The king, hands chained and wearing a thorn crown, sits hopelessly in a cell allocated to him by Temurlane. Suddenly, two spirits appear before the king telling him that he will reclaim his kingdom through the unity of his nation. And when the king tells the spirits that all of the Armenians have been massacred, the spirits answer as follows: "These are enough, do not feel sorry, thanks to unity the day will come that you will restore your monarchy [kraligin tasdik edecekler]. You are going to preserve your independence, be restful, do not detach yourself from unity, once more in the future you will regain your crown." Itidal reported that when the curtain closed all of the Armenians in the audience began shouting and applauding "Long live Armenia," "Long live Armenian kingdom," "Long live Armenians." 58

On another occasion, a performance of Hamlet by the Armenian students of St. Paul's College of Tarsus made government officials and the local mufti (Islamic scholar) uneasy. Helen Davenport (Brown) Gibbons, who taught at the school, described the play and her role in putting on the performance in detail in a letter sent to her mother on 7 April 1909. Gibbons described that when things began to go badly for Hamlet's stepfather, people stopped fanning. The attending dignitaries became uneasy, and hunched their shoulders. They kept their eyes glued to the stage. She continued:

They are not familiar with our great William, and believe, no doubt, that we invented the play as well as the actors' costumes. Horror of horrors! We had forgotten what they might read into the most realistic scene. An Armenian warning for Abdul Hamid? The assassins mastered the struggling king. He lay there with his red hair sticking out from his crown, and the muscles of his neck stiffened as he gasped for breath while his throat was cut with a shiny white letter-opener. ${ }^{59}$

In addition to these, the relationship in Adana between Armenian ecclesiastic leadership and the local government deteriorated after the 1908 revolution, particularly after the removal of the vali Bahri Pasa who had a cordial relationship with the Armenians and especially with Bishop Moushegh Seropian. ${ }^{60}$ Fearful of what might happen, the Catholicos of Sis, Sahag, sent telegrams to Istanbul warning of imminent massacres in the area. The Ottoman-Turkish newspapers of Istanbul reacted negatively to these telegrams, saying "we do not want to believe in the existence of the threat of massacre." 61 At the time, the prelate of Adana, Bishop Moushegh, was on a mission to Istanbul. When he returned to Adana he found that letters from the villages warning of imminent threats have accumulated. Bishop Moushegh also sent a pastoral letter to the Armenians of Adana emphasizing the need for harmony among the people. ${ }^{62}$ However, the uncertain situation and the rising tension led Bishop Moushegh to encourage Armenians to buy arms ${ }^{63}$ :

We advise the people, in order to be able to fulfill their duties towards the country and constitution, every person should be armed more or less according to his ability. That readiness should be at the same time somehow a means for self-defense, against an unfortunate attack, until the constitutional government comes to their aid. ${ }^{64}$

Dr. Christie, the American missionary, criticized Bishop Moushegh's words and deeds and those of the young men who were following him. He argued that it was wrong to bring tin boxes of arms and ammunition to Mersin addressed to Armenians in Adana. ${ }^{65}$ However, he explained that even these do not prove that there was an intention to 
rebel against the government. ${ }^{66}$ Thus, Bishop Moushegh in the eyes of the local Muslim population became an agitator and the source of tensions for inciting the Armenians against the Turks and encouraging them to establish Kingdom Cilicia. ${ }^{67}$ As a result, twenty-five days before the massacres Bishop Moushegh was banished from Adana to Cairo by orders from the vali. ${ }^{68}$

\section{The Consolidation of Violence: The Breaking Point}

In March 1909 ethnic tension began to deteriorate dramatically, as manifested in a couple of sporadic attacks on Armenians. ${ }^{69}$ One of these attacks became the catalyst precipitating the first wave of the Adana Massacres/Clashes. On 28 March 1909, an Armenian named Hovhannes was attacked by a group of Turks, led by a man named Isfendiar. ${ }^{70}$ During the ensuing fight, Hovhannes killed Isfendiar, wounded some of the other attackers, and fled to the Armenian Quarter in Adana. From there he escaped to Cyprus. Isfendiar's funeral attracted not only those angered by the killing, but also much of the element dissatisfied with the new order, the constitution, and its Armenian "collaborators." The body was dragged through the streets for exhibition and became a catalyst in the manifestation of the existing economic and political anxieties. This immediately led to the mobilization of the masses and prepared the ground for the enactment of violence. ${ }^{71}$ Inflammatory remarks were made in the mosques and it was proclaimed that the Armenians of Adana had risen and were "killing true believers and burning their houses." ${ }^{72}$ Isfendiar's family demanded that the vali capture the murderer. ${ }^{73}$ A few days later, one of Hovhannes's other attackers died from the wounds he received, elevating the level of anger and excitement among the Muslim population. As the situation intensified, the vali of Adana telegrammed Istanbul warning of an imminent threat in Adana. Adil Bey, on behalf of the Ministry of Internal Affairs responded, "The financial institutions along with foreign buildings should be protected and peace should be preserved" (Müessesât-i mâliye ile emâkin-i ecnebîyenin muhâfazasi ve iâde-i âsâ yise dikkatolunmasi). ${ }^{74}$ Some Armenian sources understand this telegram as an order to massacre the Armenians. ${ }^{75}$ This sentence, however, is too vague to necessarily be understood in that way. With the arrival of news about the counterrevolution from Istanbul, the situation exploded.

\section{The First Waves of Massacres/Clashes (April 14, 15, and 16)}

"What could I do, if there is Constitution.

Whatever the majority wants they will do so."76

In Adana, Tuesdays were market days. Peasants would travel from their villages to Adana in the morning and return in the evening. On Tuesday, 13 April 1909, these peasants did not return to their homes. It is also noteworthy that because of seasonal migration, 30,000-40,000 additional Armenian, Kurdish, and Turkish farm workers inhabited Adana. ${ }^{77}$ On April 14, the disturbances began. Armenians opened their shops in the early morning, but soon saw groups of Turks, Kurds, Circassians, Basibozuks, ${ }^{78}$ Cretans, and Muslim refugees along with the seasonal workers carrying hatchets, blunt instruments, axes, and swords in their hands and wearing white bandages (saruks) around their fezzes ${ }^{79}$ in various quarters of the city. ${ }^{80}$ This made the Armenians extremely anxious, 
and they quickly closed their shops. ${ }^{81}$ When the Muslims saw that Armenians were closing their shops early they too became anxious, and a rumor spread that the Armenians were going to attack them. The mob, consisting of Turks, Kurds, Fellahs, Circassians, Gypsies, and Cretan refugees along with the migrant workers, began looting and attacking the center of the town. ${ }^{82}$ Zor Ali, the police superintendent, rallied his troops and besieged the Armenian Quarter of Sabaniye. Meanwhile, Armenians took a defensive position in the Armenian Quarter and fortified themselves in houses. ${ }^{83}$

The first day of the massacres/clashes saw sporadic and unorganized attacks. On the first night, the mob began burning the Armenian Quarter. ${ }^{84}$ The attacks and the clashes intensified the next day. ${ }^{85}$ The majority of the Armenian population found shelter in Armenian churches and schools and some in foreign missions. By the third day, the mob grew as Turks arrived from Aleppo and Sivas to take part in the pillage. Since the Armenians were running short on ammunition, they asked the government for protection. ${ }^{86}$ In response, the vali organized a reconciliation meeting between Turkish and Armenian notables. ${ }^{87}$ By the fourth day the situation had calmed. It is impossible to accurately assess the number of casualties. Hundreds of wounded Armenians were taken to the Apkarian Armenian school which was turned into a hospital. Many Armenians escaped to Mersin. ${ }^{8}$ The carnage, looting, and killing lasted for three days (April 14, 15, and 16). Many Armenians were killed as well as many Muslims, some of whom were killed while attacking the Armenian Quarter. It seems that the first wave of massacres/ clashes was minor compared to the second wave that will be discussed next. Nevertheless, Armenian shops, businesses, and institutions suffered immense damage. ${ }^{89}$

\section{Public Sphere and the Transition from Verbal to Physical Violence}

Most Armenian and European sources indicate that Ihsan Fikri, the leader of the CUP in Adana, and his newspaper Itidal played an important role in inciting the masses before the initiation of the second wave of massacres. ${ }^{90}$ However, these sources do not tell us exactly what kind of discourse was being propagated by Itidal. This raises important questions about the transition from violent political discourse to physical violence. In cases of extreme escalation of ethnic tensions, during which the existing political and civil institutions are unable to contain the lawlessness and disorder of a region, the public sphere becomes the medium through which violence manifests itself. Furthermore, it contributes to the precipitation of ethnic tensions and accelerates the motives for the perpetration of violence against the vulnerable group. In the case of Adana, instead of declaring a state of siege, the local government chose to reconcile both parties who were involved in the violence by making superficial statements about coexistence and harmony. The public sphere was not restrained nor did the local government take the necessary steps to suppress provocative statements by reactionary groups. On the contrary, the printed form of communication, one of the most important components of a public sphere, was used to instigate the public against the vulnerable population. Hence, Ihsan Fikri was able to verbally attack the Armenians, using extraordinarily violent language, and to convince the masses that the Armenians had attempted a coup d'etat to establish the Kingdom of Cilicia. ${ }^{91}$ According to the British vice consul in Adana, Doughty-Wylie, every Turk in Adana was fully persuaded at the time that the Armenians had set fire to their own houses with the idea of bringing about foreign intervention. Stories about Armenian atrocities on Muslim men and women were also widely spread. ${ }^{92}$ According to Doughty-Wylie, the Turks put all of the blame on the Armenians because they 
armed themselves and because certain delegates of the Hunchak Party, and preachers like Bishop Moushegh, had urged the Armenians to openly fight the Turks and set up a principality; the Turks also believed that they had fixed a day on which to rise and rebel against the Turks. ${ }^{93}$ Although Doughty-Wylie believed that the Hunchak Party was planning something, he nevertheless argued that they represented a fraction of the people. On the contrary, he argued that such widespread destruction could not have taken place without some "secret preparation on the Turkish side," 94 demonstrating the premeditated nature of the event. ${ }^{95}$

On 20 April 1909, thousands of free copies of Itidal were distributed in the streets of Adana. In this issue, Fikri along with his colleagues Ismail Sefa ${ }^{96}$ and Burhan Nuri vehemently attacked the Armenians. ${ }^{97}$ In an article entitled "An Awful Uprising" (Müdhis bir Isyân), Sefa stated that a wave of boiling rage and independence was destroying the country. ${ }^{98}$ He argued that Armenians, like the Turks, had been oppressed for thirtythree years by the despotic regime. Then they united with the Turks and applauded their "holy revolution." However, Sefa argued that Armenians soon began preparing themselves for the ensuing uprising by stockpiling weapons. According to Sefa, once the Armenians possessed weapons, their rhetoric changed. The phenomenon of Armenian fedayees (fighters) with Mauser riffles roaming the streets alarmed the Turks. According to Sefa, the first signs of agitation occurred on Friday when two Muslim youths were killed in the Sabaniye neighborhood. He was referring to the murder of Isfendiar. Sefa argued that although the vali had assured the Turkish population that he would capture the murderer, thus restoring order, the Armenians refused to turn over the murderer. For Sefa this was nothing less than an uprising (isyân). Sefa concluded that when the Armenians, "after all this barbarism and crime," saw the profusion of soldiers and people pouring in from the villages and understood that they would not succeed, they stopped their attacks.

In the same issue, an article by Burhan Nuri posed the rhetorical question "can the Armenians establish a state?" Burhan answered that only the foolish would believe that Armenians, numbering less than two million scattered throughout the empire, could defeat the Ottoman Empire and be able to establish an independent country. ${ }^{99}$ Burhan attacked the European powers in his article saying that any European power cannot impose on the Ottoman Empire the establishment of an Armenian state in Cilicia. Burhan concluded as follows:

If the Armenians intend to form a state, the land for that state should not be in the Ottoman Empire, rather they should look for it in the poles, in the desert lands of Africa and immigrate there. They cannot reach their goal scattered in Istanbul, Adana, Aleppo, Diyarbekir, Bitlis, and Van.

In the section of Itidal on news from the provinces, an editorial lamented that Adana would be "the victim of this horrible barbarism." The editorial argued that while the Turks were striving to live with the Armenians in happiness, the Armenians caused a "huge calamity on the head of the country through the organization of an agitation."100

Armenians, according to the editorial, had arrived in Adana from Marash, Hadjin, Harput, Diyarbekir, and from the Armenian populated provinces of Anatolia. The article argued that by forming a majority in the area, Armenians hoped to create agitation and demand autonomy. ${ }^{101}$ They were encouraged in this by the success of Austria-Hungary in annexing Bosnia and Herzegovina and by the de jure independence of Bulgaria from the Ottoman Empire on 5 October 1908. For this purpose, they hoped to provoke the 
intervention of the European powers. The article concluded by saying that "looking at the painful situation, there is no doubt that they [the Armenians] were the reason of their own destruction, the Turks, and of the country." 102

The editorial board of Itidal provided its own version of the causes and reasons for the deterioration of the ethnic relations and their culmination in the massacres. Whether or not the claims made by Itidal were true, they were vital in shaping public opinion in Adana, particularly the claims regarding an Armenian conspiracy. These articles in Itidal fumed public opinion in Adana after the first wave of massacres/clashes.

\section{The Second Wave of the Massacres (April 25-27)}

When Armenians heard the news that additional troops were going to come to Adana from Mersin to help preserve order, they were elated. ${ }^{103}$ On April 25, 850 soldiers from the second and the third regiments arrived from Dede Agaç. After the regiments set up a camp in Adana, shots were fired at their tents. A rumor immediately spread that the Armenians had opened fire on the troops from a church tower in town. ${ }^{104}$ The military commander of Adana, Mustafa Remzi Pasa, made no attempt to validate these rumors, but nevertheless ordered his soldiers to strike back at the Armenians. On Sunday, April 25 at 1:00 p.m. a battalion attacked the Armenian school that housed the injured from the first wave of the massacres. Soldiers poured kerosene on the school and set it on fire with people inside. ${ }^{105}$ Regular soldiers, reserve soldiers, and mobs along with the Basibozuks attacked the Armenian Quarter. They burned down churches and schools. The conflagration in the city of Adana continued until Tuesday morning, April 27, and destroyed the entire Armenian residential quarter and most of the houses in the outlying districts inhabited by Christians. ${ }^{106}$

Another factor which precipitated the massacres was the unwillingness of Turkish troops to maintain order. Armenian sources indicate that weapons were distributed freely by the government to local civilians who took part in the massacres, looting, and carnage. The second wave of the massacres was larger in scale and more violent than the first. While the massacres in the city of Adana were taking place, rumors spread throughout the province that Armenians had revolted in Adana, killed all the Muslims, and were going to destroy the villages. This caused extreme anxiety and provoked retaliatory attacks by the Muslims on Armenian villages.

\section{Conclusion}

More than 100 years have passed since the massacres of Adana and historians continue to debate what the main causes of the massacres were. Indeed, the revolution should be regarded as the major catalyst in the deterioration of the situation. However, the massacres would not have taken place without the host of other factors mentioned in this article. The violence inflicted on the indigenous Armenian population should be understood as a manifestation of the anxieties caused by the major change within the political framework brought by the revolution. The weak institutions of the public sphere(s) in Adana played a dominant role in intensifying these anxieties and causing much distress among the local population and the notables of the ancien régime. This anxiety was not only political; rather it had serious economic ramifications at a time when modern agricultural technologies had replaced the old ones, causing much dissatisfaction among the poor migrant workers 
who were benefiting from pre-modern modes of production. Thus, the dominant role played by the migrant population in the massacres could also be interpreted as an attack on modernization, represented by drastic changes in the mediums of production.

The bloodshed that Mihrdat Noradoungian was so much worried about did materialize during the counterrevolution. What followed was two waves of clashes, massacres, pillaging, and looting. The complicity of local government officials, such as the vali Cevad Bey and the commander of the army Mustafa Remzi Pasa, is undeniable as the Military Tribunals and the investigation commissions sent from Istanbul attested. ${ }^{107}$ Worse yet was the role that one of the most important notables of Adana, Abdü lkadir Bagdadizade, and his faction played in the massacres. ${ }^{108}$ The CUP representative in Adana, Ihsan Fikri, along with Ismail Sefa, played a dominant role in shaping public opinion and transforming verbal into physical violence. ${ }^{109}$ The reaction of the central government and the CUP against the real culprits of the massacre was lenient, as the court martial's decision attested. ${ }^{110}$ Most of the key architects of the massacres mentioned above received light sentences. About fifty Muslims (some of them innocent) ${ }^{111}$ and six Armenians were sentenced to death and many were sentenced to imprisonment with hard labor. ${ }^{112}$ It seems that the CUP, having just recovered from a huge blow as a result of the counterrevolution, was afraid to take drastic action against the real culprits of the massacres because it was afraid that this would have wider effects in the region and would endanger its existence. The Adana massacres not only resulted in huge Armenian loss of life, but also led to the destruction of one of the most important Armenian economic centers in Anatolia.

\section{Notes}

1. I would like to thank Arpi Siyahian and Michael Bobelian for reading and commenting on earlier drafts of this article. Of course, I alone am responsible for this article.

2. Mihrdat Noradoungian, "Azatut'ian gině" (The Price of Freedom), Puzantion 3617, 1 September 1908, 1. Unless otherwise noted, all translations are my own.

3. "Ba'd al-dustūr" (After the Constitution), Al-Muqattam 5903, 27 August 1908, 1; "Hame'ora' ot be-mamlakhtenu" (The Incidents in Our Empire), Hashkafa-Hazvi 30, 31 July 1908, 1-2; "Los Aksont*isimiyent** os en la Asya Minor" (The Incidents in Asia Minor), El-Tiempo 10, 28 October 1908, 92.

4. "Hin rejimě wana mēch" (The ancien régime in Van), Arevelk 6918, 12 October 1908, 3; Yervant Sermakeshkhanlian, "Hin Derut'ian Sharunakut'iwně" (The Continuation of the Old Regime), Arevelk 6924, 27 October 1908, 1; “Gavar,nerun irawijagě"” (The Condition of the Provinces), Arevelk 6896, 23 September 1908, 3; "Katsut'iwně Mushi mēch" (The Situation in Mush), Puzantion 3629, 2 September 1908, 3; "Pēdk ē Vakhnal Esbar,nalik'nerēn" (We Have to Fear from Threats), Jamanag 6, 3 October 1908, 1; Yervant Sermakeshkhanlian, "Sahmanadrut'iwně chi Gordzaderwirkor" (The Constitution is Not Being Implemented), Arevelk 6919, 21 October 1908, 1.

5. "Gatsut'ian wedank'nern ew p'ortsak'arerě" (The Dangers and the Calamities of the Situation), Puzantion 3592, 31 July 1908, 2.

6. Ibid.

7. Erik J. Zürcher, “The Ides of April: A Fundamentalist Uprising in Istanbul in 1909," in State and Islam, ed. Cees van Dijk and Alexander H. de Groot (Leiden: CNWS, 1996), 64-76; David Farhi, "The Şeriat as a Political Slogan-or the 'Incident of the 31st of Mart," " Middle Eastern Studies 7, no. 3 (1971): 275-99. On the counterrevolution, see Sina Akşin, 31 [Otuz bir] Mart Olayı (The Incident of March 31) (Ankara: Sevinç Matbaası, 1970); Talat Fuat, 31 [i.e., Otuz bir] Mart İrtica (March 31st Reaction) (Istanbul: Türk Matbaası, 1911 [1327]); Cemal Kutay, 31 [i.e., Otuz bir] Mart ihtilâlinde 
Abdülhamit (Abdulhamid during the Rising of March 31) (Istanbul: Cemal Kutay Kitaplığ1 ve Tarih Sevenler Kulübü, 1977); Ecvet Güresin, 31 [i.e., Otuz bir] Mart Isyanı (The Revolt of March 31) (Istanbul: Habora Kitabevi, 1969); Mustafa Baydar, 31 [i.e., otuz bir] Mart Vak'ası (March 31st Incident) (Istanbul: Amil Matbaası, 1955); Sadik Albayrak, 31 Mart gerici bir hareket mi? (Is the 31st of March a Reactionary Movement?) (Cağaloğlu, Istanbul: Bilim-Araştırma Yayınları, [1987]); Süleyman Kâni İrtem, 31 Mart isyani ve hareket ordusu: Abdülhamid'in Selânik Sürgünü (The Revolt of the 31st of March and the Action Army: The Banishment of Abdulhamid to Salonica) (Istanbul: Temel, 2003); Mustafa Eski, 31 Mart olayınin Kastamonu'daki yankıları (The Repercussion of the 31st of March Incidents in Kastamonu) (Ankara: Ayyıldız Matbaası A.S, 1991).

8. Yunus Nadi, İhtilâl ve İnkilâb-i Osmanî: 31 Mart-14 Nisan 1325; hadisat, ihtisasat, hakayik (Ottoman Insurrection and Coup d'etat) (Dersaadet, Istanbul: Matbaayi Cihan, 1909), 35. For the other interpretation of the event on the same day, see Lütfi, “Dunki Hâl" (Yesterday's Situation), Volkan 104, 14 April 1909 (1 Nisan 1325), 1-2.

9. Nadi, İhtilâl ve İnkilâb-i Osmanî, 44.

10. Ibid., 45.

11. For a detailed contemporary description of the action army's entrance into Istanbul, see the tenvolume journal Azatarar Sharzhumn Banakin Haght'akan Mutk'n i K. Polis (The Victorious Entrance of the Freedom Action Army to Istanbul) (K. Polis: Tparan ew Gratun H.G. P'alagashean, 1909), vols. 1-10.

12. See Elie Kedourie, "The Impact of the Young Turk Revolution in the Arabic-Speaking Provinces of the Ottoman Empire," in Arabic Political Memoirs and Other Studies (London: Frank Cass, 1974), 124-61; Hasan Kayall, Arabs and Young Turks: Ottomanism, Arabism, and Islamism in the Ottoman Empire, 1908-1918 (Berkeley: University of California Press, 1997); and Bedross Der Matossian, "Ethnic Politics in Post-Revolutionary Ottoman Empire: Armenians, Arabs, and Jews in the Second Constitutional Period (1908-1909)" (unpublished doctoral dissertation, Columbia University, 2008), 203-83.

13. For a discussion on the emergence of public spheres after the Young Turk Revolution, see Der Matossian, "Ethnic Politics in Post-Revolutionary Ottoman Empire," 55-65.

14. The concept of the public sphere, which is very much associated with the experience of Europe and North America, was introduced by Jürgen Habermas in his work The Structural Transformation of the Public Sphere. Scholars have criticized and modified the theory in different ways. Habermas himself has even revisited his approach and admitted that his notion of bourgeois public sphere is a "eurocentrically limited view." Jürgen Habermas, "A Philosophico-Political Profile," interview by Perry Andersen and Peter Dews, New Left Review 151 (1985 May-June): 104. For example, in his recent writings, Habermas has shown that there is no inherent reason that the notion of public sphere must be confined to an idealized European bourgeoisie. Jürgen Habermas, "Faktizität und Geltung" (Frankfurt: Suhrkamp, 1992), 62-77, quoted in Dale F. Eickelman and Armando Salvatore, "The Public Sphere and Muslim Identities," Archives européennes de sociologie / European Journal of Sociology 43, no. 1 (2002): 92-115. Some have argued that the notion of public sphere applies to periods well before the late eighteenth century, while others challenged the distinction and relationship that Habermas envisions between "public" and "particular" realism. See, for example, Harold Mah, "Phantasies of the Public Sphere: Rethinking the Habermas of Historians," The Journal of Modern History 72, no. 1 (2000): 153-82, 158. Some have criticized Habermas's idealization of the liberal public sphere while others point out that he failed to examine other, nonliberal and non-bourgeois, competing public spheres. See Nancy Fraser, "Rethinking the Public Sphere: A Contribution to the Critique of Actually Existing Democracy," in Habermas and the Public Sphere, ed. Craig Calhoun (Cambridge, MA: MIT Press, 1992), 115. The criticism of Habermas' public sphere created new approaches to our understanding of the public sphere. See Calhoun, Habermas and the Public Sphere; Nick Crossley and John Michael Roberts, eds., After Habermas: New Perspectives on the Public Sphere (Oxford: Blackwell Publishing/ Sociological Review, 2004). First, criticism revealed the exclusionary nature of the Habermasan public sphere in its classical liberal 
form. Second, it argued for the multiplicity of public spheres or publics as opposed to the existence of one dominant public sphere. Third, it introduced the notion of counter-public or subordinate public sphere. Nancy Fraser proposes calling them subaltern counter-publics "in order to signal that they are parallel discursive arenas where members of subordinated social groups invent and circulate counterdiscourses to formulate oppositional interpretations of their identities, interests and needs" (123). This is important, because in the Ottoman case we see not only the emergence of one dominant public sphere, but also the development of competing/contending non-dominant public sphere(s). The interaction between these competing/contending public spheres would become an important catalyst in the deterioration of ethnic relations in Anatolia.

15. One of the best studies that exist on the public sphere in Muslim societies is Miriam Hoexter, Shmuel N. Eisenstadt, and Nehemia Levtzion, eds., The Public Sphere in Muslim Societies (Albany: State University of New York Press; Jerusalem: Van Leer Jerusalem Institution, 2002). See also Eickelman and Salvatore, "The Public Sphere and Muslim Identities"; Srirupa Roy, "Seeing a State: National Commemorations and the Public Sphere in India and Turkey," Comparative Studies in Society and History 48, no. 1 (2006): 200-232.

16. Harold Mah argues that what distinguishes modern from pre-modern forms of the public is the particular mode of form of the public subject. Harold Mah, "Phantasies of the Public Sphere," 165.

17. Haim Gerber, "The Public Sphere and Civil Society in the Ottoman Empire," in Hoexter, Eisenstadt, and Levtzion, Public Sphere in Muslims Societies, 75.

18. See Ami Ayalon, The Press in the Arab Middle East (New York: Oxford University Press, 1995).

19. Notably, for different ethnic groups the emergence of the political public sphere took place in different decades of the nineteenth century.

20. The Pro-Armenia, Meşveret, Şuray-i ümmet, and al-Muqattam could be regarded as the best example of such a tool.

21. The best study on the post-revolutionary press is Palmira Brummett, Image and Imperialism in the Ottoman Revolutionary Press, 1908-1911 (Albany: State University of New York Press, 2000). Although it concentrates primarily on the satirical press during the post-revolutionary period mainly on the Ottoman press - it provides important information on political discourse on the Ottoman press from the Turkish perspective. The same kind of work needs to be undertaken on the ethnic press.

22. Ibid., 25. For example, during the first two years after the revolution, about seventynine new Armenian newspapers were published in the Ottoman Empire: forty-nine in Istanbul, eight in Van, six in Izmir, and the rest in Diyarbekir, Erzincan, Trebizond, Erzerum, and Sivas. See Amalya Kirakosian, Hay Barperagan Mamuli Madenakruitiun (1794-1967) (The Literature of the Armenian Periodical Press) (Yerevan: Haykakan SSH Kulturayi Ministrut'yun, 1970), 488-89.

23. Armenians along with the Muslims began selling arms after the revolution as one of the fruits of the revolution. Famous merchants like Haigazun Bezdigian, Mihran Yolciyan, and Revin Dikran Jeridian began selling arms in Adana. Later, when the incidents began, they were accused of preparing a revolt. Karebet Çalyan, Adana Vak'ası Hakkında Rapor (Report Pertaining to the Adana Incident) (Istanbul, 1911 [1327]), 19-21.

24. David Gaunt, Massacres, Resistance, Protectors: Muslim-Christian Relations in Eastern Anatolia during World War I (Piscataway, NJ: Georgias Press, 2006); Fatma Müge Göçek, "The Decline of the Ottoman Empire and the Emergence of Greek, Armenian, Turkish, and Arab Nationalisms," in Social Constructions of Nationalism in the Middle East, ed. Fatma Müge Göçek (Albany: State University of New York Press, 2002), 15- 83; Fatma Müge Göçek, “Silences in the Turkish Republican Past: An Analysis of Contemporary Turkish-Armenian Literature" (paper presented at a workshop at the Hagop Kevorkian Center for Near Eastern Studies, New York University, 27 October 2003); Fatma Müge Göçek, "Reconstructing the Turkish Historiography on the Armenian Deaths and Massacres of 1915," in Looking Backward, Moving Forward: Confronting the Armenian Genocide, ed. Richard G. Hovannisian (New Brunswick, NS: Transaction Publishers, 2003), 209- 
30; Taner Akçam, Insan haklari ve Ermeni sorunu (Human Rights and the Armenian Question) (Istanbul: Image Press, 1999); Fatma Müge Göçek, Turk ulusal kimliği ve Ermeni Sorunu (Turkish National Identity and the Armenian Question) (Istanbul: İletişim Publications, 1994); Fatma Müge Göçek, Ermeni Tabsusu Aralanırken: Diyalogdan Başka Bir Çözum Var Mı? (While the Armenian Taboo is Being Cracked: Is There Any Solution Other than a Dialogue?) (Istanbul: Su Publications, 2000); Fatma Müge Göçek, From Empire to Republic: Turkish Nationalism and the Armenian Genocide (New York: Zed Books, 2004); Fatma Müge Göçek, A Shameful Act: The Armenian Genocide and the Question of Turkish Responsibility (New York: Metropolitan Books, 2006); Fatma Müge Göçek, Ermeni Meselesi Hallolunmustur' Osmanli Belgelerine Göre Savas Yillarinda Ermenilere Yönelik Politikalar (The Armenian Issue is Resolved: Policies Toward Armenians During the War Years, Based on Ottoman Documents) (Istanbul: Iletişim Press, 2008); Taner Timur, Türkler ve Ermeniler: 1915 ve Sonrası (Turks and Armenians: 1915 and Its Aftermath) (Ankara: Image Press, 2001); Fuat Dündar, Ittihat ve Terakki'nin Müslümanlarn iskan politikası (1913-1918) (The Muslim Settlement Policy of the Union and Progress Party) (Istanbul: Iletişim Press, 2001); Fuat Dündar, Modern Türkiye'nin Şifresi: İttihat Ve Terakki'nin Etnisite Mühendisliği (1913-1918) (The Cipher of Modern Turkey: The Ethnic Engineering of the Union and Progress [1913-1918]) (Istanbul: Iletişim Press, 2008); Fuat Dündar, Crime of Numbers: The Role of Statistics in the Armenian Question (1878-1918) (New Brunswick, NJ: Transaction Publishers, 2010); Selim Deringil, "The Study of the Armenian Crisis of the Late Ottoman Empire, or, 'Seizing the Document by the Throat,' " New Perspectives on Turkey 27 (2002): 35-59; Üngör Uğur Ümit, “When Persecution Bleeds into Mass Murder: The Processive Nature of Genocide," Genocide Studies and Prevention 1, no. 2 (2006): 173-96; Üngör Uğur Ümit, “Seeing like a Nation-State: Young Turk Social Engineering in Eastern Turkey, 19131950," Journal of Genocide Research 10, no. 1 (2008): 15-39; Üngör Uğur Ümit, "Geographies of Nationalism and Violence: Towards a New Understanding of Young Turk Social Engineering," in "Demographic Engineering - Part 1," ed. Nikos Sigalas and Alexandre Toumarkine, special issue, European Journal of Turkish Studies 7 (2008), http://www.ejts.org/document2583.html (accessed 24 March 2010). See also the collected essays in Tarih ve Toplum Yeni Yaklaşımlar 5 (Spring 2007). For a review of Turkish liberal historiography, see Bedross Der Matossian, "Venturing in the Minefield: Turkish Liberal Historiography and the Armenian Genocide," in The Armenian Genocide: Cultural and Ethical Legacies, ed. Richard Hovannisian (New Brunswick, NS: Transaction Publishers, 2007), 369-88.

25. Rarely do we see scholars working on the pre-1915 era. See Selim Deringil " "The Armenian Question is Finally Closed': Mass Conversions of Armenians in Anatolia during the Hamidian Massacres of 1895-1897," Comparative Studies in Society and History 51, no. 2 (2009): 344-71; Meltem Toksöz, "Adana Ermenileri ve 1909 'iğtişâşı' " (Armenians of Adana and the 1909 Revolt), Tarih ve Toplum Yeni Yaklaşımlar 5 (2007): 147-57; and Matthias Bjørnlund, "Adana and Beyond: Revolution and Massacre in the Ottoman Empire Seen through Danish Eyes, 1908/9," Haigazian Armenological Review 30 (2010): 125-56.

26. See, for example, Vahakn N. Dadrian, The History of the Armenian Genocide: Ethnic Conflict from the Balkans to Anatolia to the Caucasus (Providence, RI, and Oxford: Berghahn Books, 1995); Raymond H. Kévorkian, Le génocide des Arméniens (Paris: Jacob, 2006).

27. Esat Uras, Tarihte Ermeniler ve Ermeni Meselesi (Armenians in History and the Armenian Question) (Ankara: Yeni Press, 1950); Salahi Sonyel, İngiliz Gizli Belgelerine Göre Adana'da Vuku Bulan TürkErmeni Olayları (Temmuz 1908-Aralı 1909) (The Turco- Armenian "Adana Incidents" in the Light of Secret British Documents [July 1908- December 1909]) (Ankara: Türk Tarih Kurmum Baismevi, 1988). Even in their memoirs, the Ottoman officials involved in the events at the time argue that Armenians were preparing to establish their Cilician Kingdom. These are Mehmed Asaf (the mutessarif of Cebel-i Bereket), Ali Münif Bey (Adana's deputy in the parliament at the time), and Cemal Paşa (Adana's vali after the massacres). See Mehmet Asaf, 1909 Adana Ermeni Olaylari ve Anılarim (Armenian Incidents of Adana and My Memoirs), yay. haz., Ismet Parmaksizoglu (Ankara: Türk Tarih Kurumu, 1982). Asaf wrote his memoirs in order to exonerate himself from the accusations against him by Bishop Moushegh; Ali Münif Bey, Ali Münif Bey'in hâtıralar 
(hazırlayan), Taha Toros (Istanbul: İsis Yayımcılık, 1996); and Cemal Paşa, Hatıralar, Ittihat-Terakki ve Birinci Dünya Harbi (Memoirs, the Union and Progress and the First World War), haz. Behçet Cemal (Istanbul: Selek Yayınları, 1959).

28. Vahakn N. Dadrian, "The Circumstances Surrounding the 1909 Adana Holocaust," Armenian Review 41, no. 4 (1988): 1-16; Raymond H. Kévorkian with the collaboration of Paul B. Paboudjian, "Les massacres de Cilicie d'avril 1909," in La Cilicie (1909-1921) de massacres d'Adana au mandat français, ed. Raymond H. Kévorkian, Revue d'histoire Arménienne contemporaine (Tome III, 1999), 7-248; Raymond H. Kévorkian, Le génocide des Arméniens (Paris: Jacob, 2006), 97-150; Raymond H. Kévorkian, "The Cilician Massacres, April 1909," in Armenian Cilicia, ed. Richard G. Hovannisian and Simon Payaslian, UCLA Armenian History and Culture Series: Historic Armenian Cities and Provinces 7 (Costa Mesa, CA: Mazda Publishers, 2008), 339-69.

29. On economic and agricultural centrality, see Meltem Toksöz, "The Çukurova: From Nomadic Life to Commercial Agriculture, 1800-1908" (unpublished doctoral dissertation, SUNY Binghamton University, Binghamton, 2001).

30. The deputy of Adana, Ali Münif Bey, highlights this fact in his memoirs in order to demonstrate the strategic location of Adana for Armenians and the ways in which the Church became a center of revolutionary activities for the Armenian committees. In addition, he argues that during a congress of Orthodox Armenians, who had gathered in Paris in 1905, a decision was taken to establish Cilicia as an independent entity. See Ali Münif Bey, Ali Münif Bey'in hâtıralarl, 46-48.

31. Hampartsoom H. Ashjian, Atanayi Yegeherně ew Goniyayi Husher (The Massacres of Adana and the Memoirs of Konya) (New York: Gochnag Press, 1950), 15.

32. Ibid.

33. Hagop Terzian, Atanayi Kiank'ě (The Life of Adana) (Istanbul: Zareh Berberian Press, 1909), 7. For detailed information about the population, see Yeghyayan, Atanayi Hayots' Patmut'iwn, 148-51.

34. Terzian, Atanayi Kiank'ě, 6; David Fraser, The Short Cut to India: The Record of the Journey along the Route of the Baghdad Railway (Edinburgh and London: William Blackwood and Sons, 1909), 80-81; Çalyan, Adana Vak'ası Hakkında Rapor, 6.

35. According to David Fraser, about 70,000 bales of cotton are produced annually in Cilicia. Fraser, The Short Cut to India, 76.

36. Ayhan Aktar, "On Ottoman Public Bureaucracy and the CUP: 1915-1918” (paper presented at The State of the Art of Armenian Genocide Research: Historiography, Sources and Future Directions, Strassler Center for Holocaust and Genocide Studies, Clark University, 8-10 April 2010).

37. Fraser, The Short Cut to India, 77-78.

38. Henry Charles Woods, The Danger Zone of Europe: Changes and Problems in the Near East (Boston: Little, Brown, 1911), 128.

39. Garabed Ashekian, a merchant from Adana, provides detailed information about the Armenian families that were involved in local trade as well as in the fields of import and export. See Yeghyayan, Atanayi Hayots' Patmut'iwn, 157-64. See also Çalyan, Adana Vak'ası Hakkında Rapor, 2-3. The book that Çalyan wrote after the Adana Massacres provides ample information on the ways in which the interethnic relations deteriorated. It also in a sense protests the ways in which justice was served after the massacres by the different military tribunals. Çalyan was a prominent Dashnak leader in Adana and was accused by the mutessarif of Cebel-i Bereket of agitating the masses. See Asaf, 1909 Adana Ermeni Olaylari ve Anularm, 9.

40. Çalyan, Adana Vak'ası Hakkında Rapor, 3. Ferriman Duckett, The Young Turks and the Truth about the Holocaust at Adana in Asia Minor, during April, 1909 (London, 1913), 12.

41. "Mukātabāt: Mersin" (Correspondence: Mersin), Lisan al-Hal 5793, 19 August 1908, 3. For detailed information about the event see "Azatut'yan Dōně Gawarin Mēch: Mersin 28 Hulis" (The Feast of Freedom in the Province), Puzantion 3608, 20 August 1908, 1; "Mukatabāt: Mersin" (Correspondence: Mersin), Lisan al-Hal 5793, 19 August 1908, 3; “Les Province: Lettre d'Adana," 
The Levant Herald and Eastern Express, 13 August 1908, 2. On the manifestations of the constitution in Adana, see Kudret Emiroğlu, Anadolu'da Devrim Günleri: II. Meşrutiyet'in İlanı, Temmuz-Ağustos 1908 (Revolutionary Days in Anatolia: the Proclamation of the Second Constitution, July-August 1908) (Ankara: İmge Kitabevi, 1999), 188-93.

42. Terzian, Atanayi Kiank'ě, 35.

43. On Abdülkadir Bağdadizade and his anti-Armenian sentiments, see Çalyan, Adana Vak'ası Hakkında Rapor, 40-41.

44. Moushegh Seropian, Atanayi Jardě ew Pataskhanatunerě: nakhent'ats' paraganer (The Massacres of Adana and the Accountable People: Precedent Circumstances) (Gahire: Tparan Ararat-S. Darbinean, 1909), 19.

45. Çalyan, Adana Vak'ası Hakkında Rapor, 17.

46. Ibid.

47. During the reign of Bahri Paşa all three (Ihsan Fikri, Abdülkadir Bağdadizade, and Gergerlizade) were exiled. Some returned with Bahri Paşa's aid. See L. Papazian, "Shahekan Tesaktsut'iwn mě Atanayi Nakhkin Vali Pahri Bashayi Hed" (An Interesting Meeting with the Previous Vali of Adana Bahri Pasha), Jamanag 191, 15 June 1909, 1-2.

48. Ali Münif Bey, the deputy of Adana, describes the tension between Ali Gergerlizade and Ihsan Fikri and mentions that Bishop Moushegh sat on the committee that replaced Fikri with Gergerlizade. Ali Münif Bey, Ali Münif Bey'in hâtıraları, 49.

49. Terzian, Atanayi Kiank'ě, 36. Ali Münif Bey argues that Armenians benefited from this tension between the two groups. Ali Münif Bey, Ali Münif Bey'in hâtıraları, 50.

50. Çalyan, Adana Vak'ası Hakkında Rapor, 22.

51. Ibid., 41.

52. Ibid., 43.

53. F. D. Shepard, "Personal Experience in Turkish Massacres and Relief Work," The Journal of Race Development 1 (1910-1911): 327.

54. Interview with Dr. Christie of Tarsus (from an Armenian newspaper), 13 August 1909, American Board of Commissioners for Foreign Missions (ABCFM) Archives, 2.

55. "Mulhakat: Mersinden Bir Mektup" (A Letter from Mersin), İtidal 39, 12 May 1909 (29 Nisan 1325), 2-3. This report also appeared in Arabic. See "Riwayat Istiqlāl al-Arman" (The Story of the Independence of Armenians), al-Ittihad al-'Uthmani 29, 31 May 1909, 3. Mehmet Asaf also discusses the play arguing that it was the first sign of the uprising. See Asaf, 1909 Adana Ermeni Olaylari ve Anilarim, 7-8, 27-28.

56. Asaf, 1909 Adana Ermeni Olaylari ve Anılarm, 27.

57. Itidal's information about the play and its content is totally misleading. The real title of the play was Sev Hogher kam Hetin Gisher Araratyan (Black Soil and the Nights of Ararat). The play is a tragedy written by Armenian poet and playwright Bedros Turian (1851-1872). The original play is found in the Armenian Patriarchate of Jerusalem. It was performed for the first time in the Osmaniye Theater in Gedig Paşa on 6 March 1871. The ad was first published on the front page of the Menzume-i Efkâr on 5 March 1871. The play was first published after the Young Turk Revolution of 1908. The subject and plot totally differ in the original from the subject that was reported in Itidal. For the whole play, see Petros Duryan, Erkeri zhoghovatsu (Collection of Works) (Yerevan: Haykakan SSH GA Hratarakch'ut'yun, 1971), 1: 67-131.

58. “Mulhakat: Mersinden Bir Mektup," 3.

59. Helen Davenport (Brown) Gibbons, The Red Rugs of Tarsus: A Women's Record of the Armenian Massacre of 1909 (New York: The Century, 1917), 98.

60. Çalyan, Adana Vak'ası Hakkında Rapor, 3.

61. Ikdam dismissed these reports from the provinces as total fabrication for political aims. See 
Ikdam, 21 October 1908, 3. Asaf also said that Bishop Moushegh was complaining to the central government against local officials and spreading false rumors about threats against Armenians. Asaf, 1909 Adana Ermeni Olaylari ve Anlarm, 32, 34.

62. Moushegh Seropian, Atanayi Jardě ew Pataskhanatunerě, 26.

63. Thomas D. Christie to Mr. Peet, Tarsus, 6 May 1909, ABCFM Archives, 1. As a matter of fact, Christie provides one of the most excised accounts of the deterioration of the ethnic tensions after the revolution.

64. Moushegh Seropian, Atanayi Jardě ew Pataskhanatunerě, 32.

65. According to the mutessarif of Cebel-i Bereket, the weapons were brought from Cyprus to be distributed to the Armenians of Adana by convincing them that the Turks were going to kill them. Asaf, 1909 Adana Ermeni Olaylari ve Anılarm, 7.

66. Interview with Christie of Tarsus, ABCFM Archives, 2.

67. The deputy of Adana accused him of agitating the revolutionary activities of the Armenians in Adana. See Ali Münif Bey, Ali Münif Bey'in hâtıraları, 49; Asaf, 1909 Adana Ermeni Olaylari ve Anilarm, 5-7. Asaf accused him of being a member of the Dashnak party and planning for the establishment of the Kingdom of Cilicia. In his booklet composed of two letters sent to the First Military Tribunal, Artin Arslanian exonerates Bishop Moushegh of all charges saying that on the contrary he appealed for the unity of elements (ittihad-i al-anasir). The booklet furthermore criticizes the ways in which justice was performed. Arslanian himself was imprisoned by the First Military Court and, under torture, had confessed that the aim of the Armenian agitation was to establish the Kingdom of Cilicia. Artin Arslanian, Adana'da Adalet Nasıl Mahkûm Oldu (Comment la justice a été condamnée á Adana) (Le Caire - El-Kâhire, 1909 [1325]), 11.

68. Çalyan, Adana Vak'ası Hakkında Rapor, 3. Another account says that two days before the events Hovhannes escaped to Cyprus and from there to Cairo. See Asaf, 1909 Adana Ermeni Olaylari ve Anularm, 10.

69. Çalyan, Adana Vak'ası Hakkında Rapor, 13-14.

70. Hagop Terzian, Kilikioy Aghetě: akanatesi nkaragrut'iwnner, vawerat'ught'er, pashtonakan teghekagirner, $t^{\prime}$ ght'akts'ut'iwnner, vichakagrut'iwnner, amenen karewor patkernerov (The Catastrophe of Cilicia: Eyewitness Accounts, Documents, Official Reports, Correspondence, Census, with the Most Important Pictures) (Istanbul, 1912), 18-19; Çalyan, Adana Vak'ası Hakkında Rapor, 14-16; Asaf, 1909 Adana Ermeni Olaylari ve Anilarm, 10-11.

71. Stephen R. Trowbridge to William Peet, 20 April 1909, ABCFM Archives, 1; Çalyan, Adana Vak'ası Hakkında Rapor, 25.

72. Thomas D. Christie to William Peet, Tarsus, 6 May 1909, ABCFM Archives, 2.

73. Terzian, Kilikioy Aghetě, 20.

74. Çalyan, Adana Vak'ası Hakkında Rapor, 47.

75. Kévorkian, La Cilicie (1909-1921) de Massacres d'Adana au mandat français, 139. Çalyan, Adana Vak'ası Hakkında Rapor, 47-49. Even during the parliamentary debates in the post-massacre period, Armenian deputies in the Ottoman parliament understood the telegram that was sent by Adil Bey as an order to massacre the Armenians. For example, Armenian deputy Krikor Zohrab discussed the issue saying, "I saw the telegram from the Ministry of the Interior of which complaint has been made, and its purport was in keeping with the traditions of the old regime. It did not say 'Kill the Armenians,' but 'restore order.' The hon. Members know that that was the formula used under the despotic regime; formulas depend upon their interpretations and it is certain that the phrase, 'Keep order and protect the foreigners and banks in particular,' would be misunderstood there." Summary of the Debate in the Chamber of Deputies on the Adana Massacres, in Sir G. Lowther to Sir Edward Grey (received 11 May 1909), Constantinople, 4 May 1909, inclosure, no. 84.

76. Ben ne yapabilirim. Mâdemki Meşrû tiyet vardır. Ekseriyet-i âhâli ne isterse öyle yapar. The quote is attributed to the vali of Adana, Cevad Bey. See Çalyan, Adana Vak'ası Hakkında Rapor, 30. 
77. On the seasonal migration see Toksöz, "Adana Ermenileri ve 1909 'iğtişâşı,', '148-49.

78. Başıbozuks were literary known as "damaged head" meaning "disorderly" and were irregular soldiers of the Ottoman army. They were armed and maintained by the government but did not receive pay. They did not wear uniforms or distinctive badges. They were notorious for being brutal and undisciplined, thus giving the term its second, colloquial meaning of "undisciplined bandit" in many languages.

79. All Muslims who participated in the massacres were wearing the white hatbands round the fez. See Doughty-Wylie to Sir G. Lowther, Adana, 3 May 1909, inclosure 4, no. 96; Çalyan, Adana Vak'ası Hakkında Rapor, 29.

80. Lawson P. Chambers to William Peet, 4 May 1909, ABCFM Archives, 1. Lawson Chambers was the nephew of Nisbet Chambers, a Canadian-British subject, head of the American Mission in Adana.

81. Herbert Adam Gibbons to Doughty-Wylie, Mersina, 2 May 1909, ABCFM Archives, 1. Gibbons provides in the letter a lengthy account of the incidents that occurred during the first waves of massacres.

82. The Fellahs are "Turkified" Arabs who are the descendants of the Egyptian Fellahin and brought to work in the cotton fields of Cilicia.

83. P. Rigal, "Adana. Les massacres d'Adana," Lettres d'Ore, relations d'Orient (revue confidentielle des missions jésuites éditée par le siege de Lyon et publiée a` Bruxelles, Novembre 1909), 143; Shepard, "Personal Experience in Turkish Massacres," 328.

84. Duckett, The Young Turks and the Truth about the Holocaust at Adana, 24.

85. See F. W. Macallum to Dr. J. L. Barton, Adana, 19 April 1909, ABCFM Archives, 2. Macallum provides a detailed report based on the various notes made by Rev. W. N. Chambers.

86. Lawson P. Chambers to William Peet, 4 May 1909, ABCFM Archives, 8.

87. See F. W. Macallum to Dr. J. L. Barton, 5; Terzian, Kilikioy Aghetě, 54.

88. For a detailed list of the casualties and deaths, see Stephen R. Trowbridge to William Peet, 21 April 1909, ABCFM Archives.

89. For a detailed account of the damaged places, see Çalyan, Adana Vak'ası Hakkında Rapor, 31.

90. Hag-Ter, “Atanayi Yergrord Jartě” (The Second Massacre of Adana), Jamanag 179, 1 June 1909, 1-2. See also the lengthy article of Suren Bartevian, "Hayots Dēm Zrpartut'iwnk' ew 'Itidal'i Stut'iwnnerě " (False Accusations against Armenians and the Falsifications of Ittidal), Puzantion 3831, 19 May 1909, 1; Doughty-Wylie to Sir G. Lowther, Adana, 2 May 1909, inclosure 2, no. 96.

91. Fikri was tried by the Military Tribunal [Dîvân-i Harb-i Örfi] and sentenced to two years in exile for agitating the public during the massacres. From his exile in Alexandria he wrote to the Ministry of Internal Affairs complaining about the unjust accusations against him and the unfair trial. See Fikri to the High Commissioner of Egypt, 21 October 1909 (Teşrîn-i Evvel 1325), DH.MUİ.23-2/21_4 and DH.MUI.23-2/21_5 (archives).

92. See Doughty-Wyllie to Sir G. Lowther, Adana, 2 May 1909. See also Çalyan, Adana Vak'ası Hakkında Rapor, 10-13.

93. Asaf, 1909 Adana Ermeni Olaylari ve Anılarm, 21-25.

94. See Doughty-Wylie to Sir G. Lowther, Adana, 21 April 1909, inclosure 1, no. 83.

95. On the premeditated nature of the massacres see DH.MKT, 2854/6. The document includes a copy of the telegram submitted by the governmental and parliamentary investigation commission which was sent to Adana and which indicates clearly that the incidents were part of a premeditated plan (evvelce tertib ve ittihâz edilmiş bir plan). The report was submitted to the Sublime Porte on 16 June 1909 (3 Haziran 1325). For Mustafa Remzi Pasha, see Grand Vezir Hüseyn Hilmi, telegram to the Council of Ministers, 1456, 14 July 1909. See also Ministry of Internal Affairs, telegram to the Administration of Adana, 14 July 1909 (Temmuz 1325), DH.MKT, 2875/81. Doughty- Wylie 
argued that the fact that the massacres were perpetrated on the same day in distant places shows that the authorities knew of the intended massacre beforehand. Doughty-Wylie to Sir G. Lowther, Adana, 21 April 1909.

96. Ismail Sefa was an officer in the provincial administration.

97. The arguments made by Ihsan Fikri and his friends can be found in Çalyan, Adana Vak'ası Hakkında Rapor, 32-34.

98. Ismail Sefa, “Müdhiş bir Isyân” (An Awful Uprising), İtidal 33, 7 April 1909 (25 Mart 1325), 1-2.

99. Burhan Nuri, “Ermeniler Hükümet Teşkil Edebilirler mı” (Can Armenians Form a Government), İtidal 33, 7 April 1909 (25 Mart 1325), 1-2. Even after the second wave of massacres, Fikri continued to claim that the main reason for the disturbances was the Armenians' quest to establish their kingdom. See Ihsan Fikri, "Ermeni Hemşerilerimize: İtilafa Doğru" (To Our Compatriot Armenians: Toward Entente), İtidal 37, 4 May 1909 (18 Nisan 1325), 1-2.

100. “Vilayat Havadisi” (Incidents in the Province), İtidal 33, 7 April 1909 (25 Mart 1325), 2.

101. Arslanian, who lived among Armenians for four years, had not found any desires by the local population for separation because such a thing would have been impossible. Arslanian, Adana'da Adalet Nasıl Mahkûm Oldu, 17. The same argument was made by Çalyan, who claimed that after the revolution the Armenian committees did not have any desire to promote separatist tendencies and that it would have been impossible to separate because they did not form a majority in any of the provinces. On the contrary, he argues that their first task became to preach brotherhood among all the elements of the empire. Çalyan, Adana Vak'ası Hakkında Rapor, 14, 18-19. On the other hand, Mehmed Asaf argues that Moushegh brought Armenians from Maraş, Zeytun, Van, Harput, Diyarbekir, Bitlis and had been seeking to settle them in Adana in order to alter the demographic composition. Asaf, 1909 Adana Ermeni Olaylari ve Anlarm, 24.

102. "Vilayat Havadisi," 2.

103. Terzian, Kilikioy Aghetě, 94.

104. See Doughty-Wylie to Sir G. Lowther, Adana, 7 May 1909, inclosure 3, no. 103. The vice-consul argues that some of the Roumeliot soldiers indicated that the shots that were fired at them and started the whole affair had been fired by Turks either with the wish to bring about a quarrel between the different sorts of soldiers or to raise more hope to rush the hated Armenian Quarter. See also Woods, The Danger Zone of Europe, 135.

105. Hampartsoum H Ashjian, Atanayi Yegeherně ew Goniyayi Husher (The Massacres of Adana and the Memoirs of Konya) (New York: Gochnag Press, 1950), 55. See also Lawson P. Chambers to William Peet, 4 May 1909, ABCFM Archives, 10.

106. Woods, The Danger Zone of Europe, 137.

107. See note 95 above.

108. See Ministry of Internal Affairs, telegram to the Vilayet of Adana, 11 July 1909 (28 Haziran 1325), DH.MKT, 2872/68.

109. See Ministry of Internal Affairs, telegram to the Prime Minister, 12 July 1909 (29 Haziran 1325), DH.MKT, 2873/58.

110. Çalyan is extremely cynical in terms of the way that justice was achieved in Adana. See Çalyan, Adana Vak'ası Hakkında Rapor, 36-55. The phase of the court martials, the Military Tribunals, and the government/parliamentary investigation commissions is the subject of a separate study. The trials were conducted in a manner unsatisfactory to the Armenians, who were extremely angry when the court's decision was announced. Nine Muslims and six Armenians were subjected to capital punishment in the autumn of 1909. In addition, twenty-five Muslims were hung in December 1909. These included the mufti of Bahçe. Armenians condemned the court for hanging six innocent Armenians. Articles and booklets were written denouncing the court's decision. Kassab Missak, one of the Armenians who were hung became the symbol of injustice 
for Armenians. Some even represented him as the Armenian Dreyfus. See Arslanian, Adana'da Adalet Nasil Mahkûm Oldu, 13. Armenian sources also indicated that some of the Turkish peasants who were hung were innocent. The real culprits of the Adana Massacres escaped justice. Besides the Military Tribunals, two other official bodies were sent to Adana on May 12 to investigate the massacres. Faiz Bey and Harutiwn Mosdichian were sent on behalf of the government by the Ministry of Justice, and Hagop Babigian and Yusuf Kemal Bey were sent by the parliament. Babigian and Kemal Bay were accompanied by the mutessarif of Mersin. Both bodies conducted their investigations in Adana and were supposed to send their official reports to their respective bodies. On Babigian's report, see Hagop Babigian, Atanayi Egherně (The Massacres of Adana) (Istanbul: Ardzagang Press, 1919); Yusuf Kemal Tengirşenk, Vatan Hizmetinde (Istanbul: Bahar Matbaasi, 1967), 110-24.

111. Arslanian, Adana'da Adalet Nasıl Mahkûm Oldu, 12. Other sources provide the number 41 for the Muslims who were hung. See 1909 Adana Olaylari, http://www.adanayorum.com/haber detay. asp?haber=14896 (accessed 29 April 2009).

112. See, for example, War Ministry, telegram to the Ministry of Internal Affairs, 23 November 1909 (10 Teşrîn-i Sânî 1325), DH.MUİ, 43-1/32_2. The same orders were sent to Adana on 25 November 1909 (11 Teşrîn-i Sânî, 1325). See DH.MUİ, 43-1/32_1; War Ministry, telegram to the Ministry of Internal Affairs, 22 November 1909 (9 Teşrîn-i Sânî, 1325), DH.MUi, 43-1/23_2. The same orders were sent to Adana on 23 November 1909 (10 Teşrîn-i Sânî, 1325). See DH.MUİ, 43-1/23_1.

Bedross Der Matossian is Assistant Professor of Modern Middle East History in the Department of History at the University of Nebraska/Lincoln. Born and raised in Jerusalem, he is a graduate of the Hebrew University of Jerusalem, where he began his graduate studies in the Department of Islamic and Middle Eastern Studies. He completed his PhD in Middle East History in the Department of Middle Eastern, South Asian, and African Studies at Columbia University in 2008. His dissertation, entitled Ethnic Politics in Post-Revolutionary Ottoman Empire: Armenians, Arabs, and Jews in the Second Constitutional Period (1908-1909), dealt exclusively with interethnic politics during the first year of the Second Constitutional Period (1908-1918). From 2008 to 2010, he was a lecturer of Middle East history in the Faculty of History at the Massachusetts Institute of Technology where he taught a variety of courses pertaining to world history, Islam and the West, political history of the modern Middle East as well as the Arab-Israeli conflict. His areas of interest include ethnic politics in the Middle East, interethnic violence in the Ottoman Empire, the social and economic history of the Middle East in the nineteenth and twentieth centuries, and modern Armenian history. 